\title{
对港口与航道工程混凝土配合比设计和施工的探析
}

钟健林唐文平

广西新港湾工程有限公司

DOI:10.32629/hwr.v3i4.2038

[摘 要] 现如今, 我国的港口巷道建设水平明显提高, 因此对港口巷道建设也提出了更高的要求。相关人员应从设计环节入手 对其予以高度重视, 合理设计混凝土的配合比, 保证混凝土强度充分满足工程建设的要求, 同时加强混凝土的耐久性, 不断提高 工程建设的经济效益和社会效益。

[关键词]港口巷道; 设计环节; 混凝土强度

港口航道的强化要求港口航道有着较高的质量, 需要在 工程施工过程注意不同环节的施工, 使得工程的整体得到提 升。港口航道工程施工中, 混凝土配合比是极为重要的内容, 其具有很强的强度以及耐久性, 经济性也比较好, 能够提高 港口航道工程施工的整体质量。因此需要对港口航道施工混 凝土配合比提高重视, 保证设计的科学性和有效性, 提高整 个工程的质量和安全性。

\section{1 港口与航道工程混凝土配合比设计和施工的价值}

港口与巷道工程对区域综合交通运输网络的建构有着 积极的意义, 其推动这区域经济的建设和发展。同时其无需 占用大量的航运用地, 投资成本较低, 货运量较大, 且运费较 低, 能源消耗较少, 充分利用其自身的优势能够全面满足当 前交通网络建设的总体要求, 进而推动商品贸易的持续前 行。在现代交通网络运输建设的过程中, 混凝土在港口巷道工 程中发挥着关键作用, 混凝土的配合比直接影响了航道工程 建设的质量, 所以在工程建设中有必要将其作为核心控制点。

\section{2 混凝土配合比设计}

2.1 混凝土原材料选择

首先是水泥的选择, 在选择水泥时应结合项目的实际情 况合理选择水泥材料, 水泥材料当中的硅酸三钙在材料中所 占的比重应为 $6 \%-12 \%$, 其也比较适合应用在港口工程的建设 和施工当中。在工程施工中使用的水泥标号在 32.5 级以下。 港口工程建设中的混凝土会受到水体的影响。因此为了保证 混凝土的质量, 施工人员需结合工程实际选择腐蚀性较强的 水泥。施工单位在施工中选择使用粉煤灰水泥、火山泥和矿 渣泥时, 要高度重视配合比的设计工作, 且在材料中加入适 量的碱水。若港口施工主要面对淡水的环境, 则工作人员需 使用含碱量不高于 $0.6 \%$ 的水泥。

集料主要由粗骨料 (如图 1 所示)、细骨料、掺合料(外加 剂) 等构成。港口工程建设和施工过程中所选择的粗骨料多为 坚硬的碎石和卵石, 选择粗骨料的过程中, 粗骨料的强度应为 混凝土强度的 1.5 倍以上。粗骨料的压碎指标不得超过 $10 \%$, 在水体环境中尤其是水体具有显著腐蚀性时, 施工单位不应 在工程建设中使用活性粗骨料, 同时还要在选择粗粗骨料的 过程中, 严格按照国家的标准和要求保证粗骨料的各项性能。

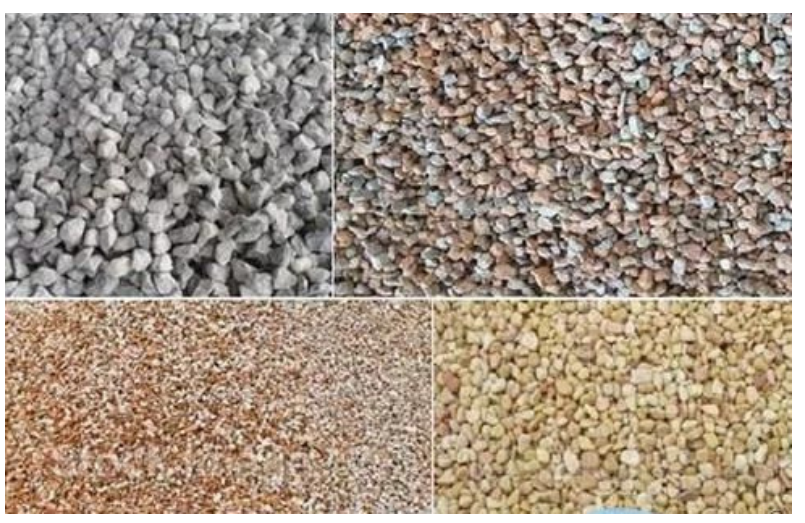

图 1 粒径大于 $5 \mathrm{~mm}$ 的骨料称为粗骨料

细骨料的选择也尤为关键, 在工程施工中若选择细骨料, 则应选择粒径在 $0.5 \mathrm{~cm}$ 以内的岩石碎块, 在混凝土配比的过 程中, 需结合工程的基本需求决定细骨料的细度模数, 规定 粗砂的细度模数为 3.7-3.1, 中砂的细度模数为 3.0-2.3, 细 砂的细度模数为 2. 2-1.6, 特细砂的细度模数为 1.5-0.7。

另外, 外加剂的选择也格外关键。在为港口工程选择外 加剂的过程中, 可选择膨胀剂、减水剂、防冻剂以及早强剂 等多种外加剂, 工程企业的施工人员需充分结合工程的具体 情况合理选择外加剂。同时在应用外加剂前严格检查外加剂 的质量和性能, 并对外加剂进行专业的性能检验。待其满足 混凝土添加剂标准规范的要求后, 方可应用在工程建设和施 工当中。

在施工用水的选择中, 应根据具体施工环节和要求来选 择不同的水体, 水体不同, 混凝土的强度和钢筋的保护能力 也存在着差异。所以, 为了保证混凝土工程的施工质量, 应选 择氯离子含量不超过 $200 \mathrm{mg} / \mathrm{L}$ 的饮用水。并在混凝土拌合施 工中, 也可使用海水, 但是海水不能应用在包裹混凝土的工 程结构当中。若在工程建设中, 对混凝土的抗冻能力有着严 格的要求, 则工作人员需适度降低水灰比, 若拌合工作中所 使用的水源为矿泉水, 则要保证水体当中的硫酸盐比重在 $0.2 \%$ 以内, 且水体的 PH 值在 4 以上。

2.2 配置混凝土的强度

混凝土的设计强度 $\pm 1.645 \sigma$ 即为混凝土施工配制的强 
度。若选择 C20 或 C25 强度等级的混凝土, 则其强度标准差 不得大于 $2.5 \mathrm{MPa}$, 计算配置强度所采用的混凝土立方体抗压 标准差为 $2.5 \mathrm{MPa}$ 。如混凝土等级为 C30 以上, 则其强度的标 准差不得超过 3.0MPa, 计算配制强度所使用的混凝土立方体 抗压强度标准差即为 $3.0 \mathrm{MPa}$ 。

\section{3 水灰比}

选择水灰比的过程中应高度重视混凝土强度和耐久性 的基本需求, 混凝土的适配强度为水泥的强度与水灰比 -0.52 的乘积。因此混凝土强度与水泥强度存在正相关关系, 而其与水灰比则为负相关关系。所以, 在确定水灰比的过程 中, 要明确水灰比与水泥强度和混凝土强度之间的关系, 这 里水灰比与坍落度之间并无明显的关系。在计算水灰比的过 程中, 要在水灰比与强度之间建立准确的关系, 以坉落度为 基础选择施工材料, 拌制混凝土拌合物, 并准确绘制强度与 水灰比间的曲线。

\section{4 混凝土砂率}

粗集料需要与水泥混合, 因此其对含砂率有着十分严格 的要求, 其一方面应达到和易性的标准, 加入适量的水, 另一 方面还需在确定混凝土砂滤的过程中根据单位的实际情况 来确定含砂率。若条件完全相同, 则需先明确混凝土拌合物 的坍落度, 坍落度最大时的含砂率即为最佳含砂率。

\section{5 明确水泥使用的数量}

按照水灰比和最佳含砂率可完成不同水泥量混凝土的 拌和工作, 同时对其坉落度予以科学检测, 绘制坉落度与水 泥用量之间的曲线, 根据曲线来确定水泥的使用量。若水泥 混凝土的耐久性要求较为严格, 则应在不添加减水剂的条件 下明确水泥的用量。针对耐久性要求较高的大体积混凝土, 则要以混凝土的耐久性来控制水泥的水化热, 并在此基础上 确定水泥的实际用量。

2.6 砂石的使用数量

混凝土材料中的砂石使用量必须采用体积法的计算方 式加以确定。

\section{7 配合比的确定}

充分结合材料的基本使用情况和佣落度等数据来确定 混凝土的配合比, 且做好复核工作, 确定混凝土配合比的过 程中主要可将其分为三个环节, 分别为初步计算、调整试样 以及确定配合比, 经上述三个环节确定最佳配合比。

在港口工程施工中, 配合比设计与确定尤为关键, 应结 合工程建设和施工实际、工程的施工工艺、要求和环境等参 数来明确混凝土施工技术的多种性能, 然后根据不同的材料 和使用比例来确定混凝土的技术性能。

\section{3 港口与航道工程混凝土施工中的注意事项}

3.1 严格把控混凝土质量

港口与巷道工程的施工质量对我国水运行业的发展有 着较大影响, 因此在混凝土施工中应严格依据工程建设和施
工的规范和要求完成工程建设。混凝土在工程建设中是一种 应用较为普遍且规模较大的材料, 混凝土的性能也对工程的 施工质量有着显著影响。在工程设计和施工中混凝土配合设 计方案的执行十分关键, 施工中不可随意变换施工工艺, 且 严格的施工管理有利于提高混凝土的稳定性, 管理人员应在 工程施工中严格控制多个环节的施工规范性, 进而不断提高 工程的施工水平。

\section{2 钢筋层的控制}

钢筋和混凝土在工程施工中是用量最大的施工材料, 若 只有混凝土而没有钢筋的支持, 则工程施工无法顺利进行, 只有钢筋与混凝土有机结合才能更好地展现出二者的积极 作用和价值。钢筋的抗拉伸和韧性较强, 故而其在应对工程 设施所产生的应力方面具有积极的作用。混凝土配合比通常 是以设计阶段的基本规定来进行工程建设。工程施工中, 需 严格把控工程质量。钢筋选型在其中发挥着重要的作用, 钢 筋的型号和规格必须满足设计的基本规范和要求, 从而不断 提高工程的施工质量。在工程建设中, 还需高度重视钢筋和 混凝土的配比, 这样方可在增强工程施工精度的同时, 保证 工程的施工质量。

\section{3 预制混凝土}

港口与巷道工程的施工条件具有特殊性, 部分工程需在 水环境中完成, 这也对混凝土配比设计提出了更高的要求。 且场地和时间也会受到较大的限制。所以应当在路堤上做好 混凝土预制工作, 一方面要保证工程质量, 另一方面还需改 进工程施工效率。

\section{4 防水涂料}

由于港口与航道工程中有部分结构是处于水下的, 而混 凝土结构长期受到水的侵蚀会降低自身性能和使用寿命, 所 以应该做好混凝土结构保护工作。一般会在混凝土结构上涂 抹防水涂料, 起到隔离防护的作用。所以防水涂料的质量非 常重要, 一定要选用优质的涂料, 确保涂层的防护性能。

\section{4 结束语}

综上所述, 港口与航道工程对我国社会经济的发展起到 了重要的推动作用, 港口与航道工程是我国水运事业的关键 枢纽, 故而切实加强与提升港口与航运工程的施工质量非常 必要且重要。而混凝土是工程施工中的重要材料, 由于工程所 处环境的特殊性, 部分结构需要长期处于水下, 所以混凝土结 构会面临各种应力以及侵蚀的影响, 从而降低使用性能。

\section{[参考文献]}

[1]李牧野,彭博.对港口与航道工程混凝土配合比设计 和施工的探析[J].珠江水运,2017,(17):65-66.

[2]张祖臣.港口与航道工程混凝土配合比设计和施工的 探析[J].建材与装饰,2018,(06):85-86.

[3]张亚萍.解析港口与航道工程混凝土配合比设计和施 工[J].科技展望,2015,25(02):40. 